portion of the cornea is hidden by the inner canthus. This want of control renders it very difficult to make a satisfactory ophthalmoscopic examination, but as far as can be made out the fundus oculi is normal ; indeed, the functional activity of the optic nerves since the cataracts were removed is very remarkable and is in striking contrast to the purposeless muscular movements. Disuse has crippled the function of the latter, but seems to have had but little effect on the activity of the former. The eye is a receptive organ and the light that gained access to the retina through the opaque lens proved stimulus sufficient to maintain the optic nerve in health, while the want of visual power deprived the coördinating centre in the brain of all stimulus to develop and hence the ocular muscles are not trained to obey the dictates of the will

I am indebted to Mr. W. G. MacDonald, one of my students, for bringing this case under my notice.

Glasgow.

\section{SOME OBSERVATIONS ON THE BLOOD GASES IN DIABETES.}

By A. P. BEDDaRD, M.A., M.D. Cantab., assistaNT PHYSICIAN, GUY's hOSPITAL; PHYSTCLAN, WEST LONDON HOSPITAL;

M. S. PEMBREY, M.A., M.D. OxoN., LECTURER IN PHYSTOLOGY AT GUY'S HOSPITAL; AND

E. I. SPRIGGS, M.D. LOND.,

PHYSICIAN TO OUT-PATIENTS TO THE TICTORIA HOSPITAL FOR CHILDREN, CGELSEA, AND TO THF CITY OF LONDOX HOSPITAL FOR DISEASES OF THE CHEST, VICTORIA-PARK; DEMONSTRATOR OF PHYSIOLOGY AND GULI RESFARCH STUDENT IN PATHOLOGY, GUY'S HOSPITAL.

(From the Physiological Laboratory, Guy's Hospital.)

Minkowski and Stadelmann were, so far as we know, the founders in the early "eighties" of the view that in diabetic coma we have to deal with an acid intoxication. In the 20 years which have since elapsed this view has steadily gained ground.

It has been shown by Walter that a condition of unconsciousness with deep respirations can be produced in herbivora by the action of acids put into the stomach, and in these animals the alkalinity of the blood was diminished and its content of carbon dioxide was reduced from 32 to 2 or 3 volumes per cent. In carnivora similar results have been obtained though with less ease, owing to the chemical mechanism by which flesh-eaters are able to neutralise considerable quantities of acid by the production of ammonia. In man it is known that the alkalinity of the blood is diminished in diabetic coma and Kraus (confirming Minkowski) found the $\mathrm{CO}_{2}$ content of the blood constantly low in 13 cases of diabetic coma. The average was about 15 volumes per cent., with a maximum of $19 \cdot 8$ and a minimum of 98 volumes per cent. In some of these cases titration of the bluod was carried out and the alkalinity was found to be depressed.

We have made estimations of the carbon dioxide in the blood and its alkalinity in 23 samples of blood from 15 cases, eight being cases of diabetic coma, three of diabetes without coma, and four being from cases of odema of the lung, pancreatic disease, pernicious anæmia, and ascites respectively. We have also estimated in eight cases the carbon dioxide in the urine and in six cases the capacity of the blood and urine to take up that gas. In two of the cases of diabetic coma the ammonia, the oxybutyric acid and acetone, and the total nitrogen in the urine were also estimated dally, as well as the nitrogen in the food. Histological examinations of the pancreas have been made in tive fatal ca:es.

The gases in the blood were estimated with Hill's blood pump, live or more cubic centimetres being taken for the analysis trom a vein by means of an antitoxin syringe In several cases duplicate estimations were also made with the apparatus of Barcroft and Haldane. The alkalinity of the blood was estimated by Wright's method and is exuresse ${ }^{+}$ below in terms of normal alkali. The avtrage alkalinity of healthy serum corresponds, according to Wright, to about. $\frac{N}{30}$ higher-e.g., from $\frac{\mathrm{N}}{25}$ to $\frac{\mathrm{N}}{30^{\circ}}$.

We are deeply indebted to the physicians of Guy's Hospital for permission to investigate their cases and especially to Dr. Newton Pitt under whose care were five of the patients.

An account in full of the observations, which commenced last October and are still in progress, will in course of time be published. The accompanying table gives some of the more important figures which have been obtained.

TABLE OF RESUlts.

\begin{tabular}{|c|c|c|c|c|c|c|c|}
\hline & Remarks. & Date. & 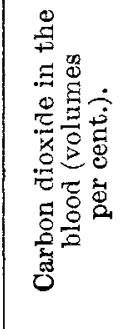 & 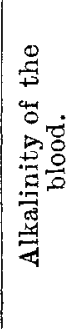 & 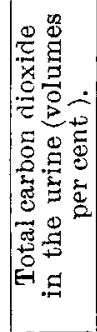 & 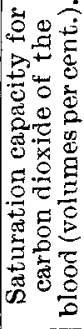 & 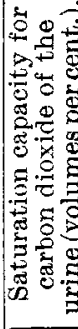 \\
\hline & Diabetic coma. & $\begin{array}{l}\text { Oct. 14th, } \\
1902 .\end{array}$ & $13 \cdot 0$ & $\frac{N}{70}$ & - & - & \\
\hline & $\left.\begin{array}{c}\text { After alkali ad- } \\
\text { ministration. }\end{array}\right\}$ & $\begin{array}{l}\text { Oct. 15th, } \\
1902 .\end{array}$ & $16 \cdot 8$ & - & - & - & \\
\hline 2 & Diabetic coma. & $\begin{array}{l}\text { Oct. } 17 \text { th } \\
1902 .\end{array}$ & $24 \cdot 0$ & $\frac{N}{80}$ & - & - & \\
\hline 3 & Diabetic coma. & $\begin{array}{l}\text { Dec. 2nd, } \\
1902 .\end{array}$ & $14 \cdot 8$ & $\frac{N}{57}$ & - & - & \\
\hline & After alkali. & $\begin{array}{l}\text { Dec. 3rd, } \\
1902 .\end{array}$ & 一 & $\frac{N}{50}$ & - & 220 & \\
\hline & Later. & $\begin{array}{l}\text { Dec. 3rd, } \\
1902 .\end{array}$ & $\left\{\begin{array}{l}(a) 13 \cdot 8 \\
(b) 13 \cdot 7\end{array}\right.$ & $\frac{N}{45}$ & $5 \cdot 1$ & - & \\
\hline & Later. & - & - & $\frac{N}{45}$ & 一 & - & \\
\hline 4 & Diabetic coma. & $\begin{array}{l}\text { Dec. 14th, } \\
1902 \text {. }\end{array}$ & $\left\{\begin{array}{l}(a) 22 \cdot 8 \\
(b) 22 \cdot 1\end{array}\right.$ & $\frac{N}{60}$ & $5 \cdot 0$ & 301 & \\
\hline 5 & Diabetes. & $\begin{array}{l}\text { Dec. 19th, } \\
1902 \text {. }\end{array}$ & $33 \cdot 4$ & $\frac{\mathbf{N}}{32}$ & $7 \cdot 1$ & 208 & \\
\hline & $\left.\begin{array}{c}\text { After alkali } \\
\text { some days. }\end{array}\right\}$ & $\begin{array}{l}\text { Feb. 19th, } \\
\text { 1903. }\end{array}$ & $28 \cdot 1$ & $\frac{N}{30}$ & $8 \cdot 9$ & 238 & 3 \\
\hline 6 & Diabetes. & $\begin{array}{l}\text { Feb.9th } \\
\quad 1903 .\end{array}$ & $24 \cdot 2$ & $\frac{N}{45}$ & - & - & \\
\hline$?$ & Diabetic coma. & $\begin{array}{l}\text { Feb. } 9 \text { th, } \\
1903 .\end{array}$ & $20 \div 1$ & $\frac{N}{90}$ & - & - & \\
\hline & $\left.\begin{array}{c}\text { After alkali ad- } \\
\text { ministration }\end{array}\right\}$ & $\begin{array}{l}\text { Feb 9th, } \\
\text { 1903. }\end{array}$ & - & $\frac{N}{50}$ & - & - & \\
\hline & & $\begin{array}{l}\text { Feb. 11th, } \\
1903 .\end{array}$ & $25 \cdot 5$ & $\frac{N}{30}$ & - & - & \\
\hline 8. & Dyspncea. & $\begin{array}{l}\text { Feb. 17th, } \\
1903 .\end{array}$ & $43 \cdot 0$ & $\frac{\mathbf{N}}{27}$ & $11 \cdot 1$ & - & \\
\hline & & $\begin{array}{l}\text { Feb. 20th, } \\
1903 .\end{array}$ & $38 \cdot 8$ & $\frac{\mathbf{N}}{27}$ & $8 \cdot 4$ & 242 & \\
\hline 9 & $\left\{\begin{array}{c}\text { P a n creatic } \\
\text { disease. }\end{array}\right\}$ & $\begin{array}{l}\text { Feh. 21st, } \\
1903 .\end{array}$ & $56 \cdot 5$ & $\frac{N}{20}$ & -- & - & $87 \cdot 1$ \\
\hline & Ascites. & $\begin{array}{l}\text { Feb. 26th } \\
1903 .\end{array}$ & $48 \cdot 5$ & $\frac{N}{25}$ & $6 \cdot 7$ & 226 & 139 \\
\hline 11 & Diabetic coma. & $\begin{array}{l}\text { March 17th, } \\
\quad 1903 .\end{array}$ & $\left\{\begin{array}{l}14 \cdot 1 \\
12 \cdot 2\end{array}\right.$ & $\frac{N}{45}$ & - & - & \\
\hline & $\begin{array}{c}\text { Afteralkali (arm } \\
\text { bandiaged for } \\
4 \text { minutes). }\end{array}$ & $\begin{array}{l}\text { Mareh } 1^{2} \mathrm{th}, \\
\quad 1903 .\end{array}$ & $39 \cdot 0$ & $\frac{\mathrm{N}}{\varepsilon 7}$ & - & - & \\
\hline 2 & $\left\{\begin{array}{l}\text { Pernicious } \\
\text { anæmia. }\end{array}\right\}$ & $\begin{array}{l}\text { Marrh 30th, } \\
1903 .\end{array}$ & $43 \cdot 2$ & $\frac{N}{25}$ & $\left\{\begin{array}{l}2 \cdot 7 \\
26\end{array}\right.$ & - & \\
\hline & Diabetic coma. & $\begin{array}{l}\text { May 4th, } \\
1903 .\end{array}$ & $25 \cdot 8$ & $\bar{N}$ & - & - & \\
\hline 4 & Diabetic coma. & $\begin{array}{l}\text { Mav 4th } \\
1903 .\end{array}$ & $17 \cdot 6$ & $\frac{N}{40}$ & - & - & \\
\hline 15 & Diabetes. & $\begin{array}{l}\text { May 6th, } \\
1903 .\end{array}$ & $52 \cdot 0$ & $\frac{N}{25}$ & - & - & \\
\hline
\end{tabular}

1 Some of our results were brought before the Medical Research. Society on Feb 18th last and ther are referrer to in THE LANCET of March 14 th, p. 715 , in a paper by Dr. Hale White. 
It will be seen from the table that in all the cases of diabetic coma which had not been treated with alkali the quantity of carbon dioxide which could be extracted from the blood was half or less than half the normal. The usual figure given for healthy venous blood is from 40 to 50 volumes per cent. In the blood of the non-comatose patients there was less $\mathrm{CO}_{2}$ than in normal blood but more than in coma. In this series the depression of the alkalinity of the blood and the diminution in the $\mathrm{CO}_{2}$ content run approximately parallel except when sodium carbonate or bicarbonate had been given. In the diabetic cases diacetic acid and acetone were present in the urine. The quantity of ammonia is usually regarded as a rough guide to the amount of oxybutyric acid and diacetic acid in the urine, though this assumption is not now without its objections. In two cases direct estimations were made of the oxybutyric acid, acetone, and the ammonia. The proportion of the total nitrogen excreted as $\mathrm{NH}_{3}$ was high, varying from 12 to 25 per cent. In one case this high proportion was diminished by giving alkali and in another it was not.

The theory has been advanced, and is current to some extent, that in diabetic coma the blood is unable owing to its diminished alkalinity to take up the normal amount of $\mathrm{CO}_{2}$ and thus that the tissues are overcharged with this gas. We have made four observations upon the tension of $\mathrm{CO}_{2}$ in the blood of two cases, one of diabetes and one of diabetic coma. We have not found the amount of the gas in the urine of diabetes to be above normal. Complicated physical and chemical points are involved in the interpretation of this result, but it certainly lends no support to the theory that the tissues, in contact with which this urine has been lying, are loaded with an excess of $\mathrm{CO}_{2}$. We have also passed $\mathrm{CO}_{2}$ through diabetic blood and urine. In each case the fluid was able to take up a large quantity of the gas and there appears to be no physical disability of the blood to take up more $\mathrm{CO}_{2}$

As against the view that the tissues are loaded with $\mathrm{CO}_{2}$ more favour has been given on the continent to the conception that in diabetes, owing to the acids produced by the morbid metabolism, the cells of the body are (from deprivation of alkali) unable to carry on the usual oxidative processes and that in coma this inability to utilise oxygen becomes acute and the cells, including those of the respiratory centre, are in a state of oxygen starvation, although there is plenty of oxygen in the blood.

From the consideration of the above experiments and from others now in progress we think that in diabetic coma the respiratory symptoms are not entirely to be explained by the assumption of a chemical disability of the blood to combine with carbon dioxide.

\section{SURGICAL EMERGENCIES IN GENERAL PRACTICE.}

BY GEORGE A. CLARKSON, F.R.C.S. ENG.

THE two following cases afford good examples of acute abdominal conditions requiring active surgical interference.

CASE 1.-The patient, a man, aged 49 years, was first seen at 2.30 P.M. on Feb. 1st, 1903. He was lying in bed, evidently in considerable pain and with an anxious expres sion. Asked what was the matter he immediately pointed to a hard semilunar swelling of the size of an orange immediately to the left of the umbilical cicatrix. The history was to the effect that he had not been well for some days, being troubled with aching in the limbs, cough, and wheezing. Not feeling any better that morning he had stayed in bed and about noon, during a violent fit of coughing, he felt a sudden pain and almost immediately noticed the swelling in question. Before this took place the bowels had acted naturally. He had not vomited at all, but he complained of increasing pain in the hernia, which he described as getting harder and harder. An operating table was improvised without delay in an adjoining room and within the space of an hour the operation was begun. The patient was a particularly bad subject for an anæesthetic as, in addition to some bronchial catarrh, his face was very congested from dilated venules, his arteries were thickened and rigid, and some years previously he had suffered from acute rheumatism with cardiac complications. Ether was the anæsthetic given. A free incision was made over the hernia and the sac was rapidly and freely opened. It contained much fluid under considerable tension and a loop of very congested small intestine tightly gripped at the neck of the sac which was quite small. The hernia was quite recent. There were no adhesions and no omental lining to the sac. The stricture was divided in an upward direction, the bowel was reduced, and the sac was stripped up to the ring, ligatured, and cut off. The opening in the rectus muscle was then closed with strong silk and the wound was sewn up. Except for some bronchitis, which was troublesome for the first two days, the patient made an uninterrupted recovery. The stitches were removed on the tenth day and at the end of a fortnight the patient was able to get up.

Two interesting points about the case are: (1) that four hours had intervened between the time of strangulation and the time that the sac was opened; and (2) that though the gut was very congested and very tightly gripped no vomit. ing had occurred.

OASE 2.-The patient was a well-nourished and healthylooking boy, aged two years. For some two or three months he had had occasional attacks of abdominal pain believed to be dne to flatulence. On the evening of April 2nd, 1903, he was seized with sudden pain in the abdomen which made him scream out and very shortly afterwards he passed a considerable amount of bright blood per rectum unmixed with mucus. When seen shortly after this had occurred the child was quite collapsed, the pulse was rapid, and there were evidently occasional paroxysms of pain. The abdomen was rather distended and rigid so that nothing pointing to the exact condition inside could be made out. The rectum contained a little bright blood and nothing abnormal could be felt in it. On the following morning the child was obviously worse, paroxysms of pain occurred about every quarter of an hour, the pulse was very rapid, and the temperature was subnormal. During the night vomiting had commenced and had continued at short intervals. Nothing further was disclosed by palpation of the abdomen or by rectal examination. The child being obviously very ill indeed an operation was advised. This was carried out in the afternoon under chloroform. When the abdominal walls were well relaxed under the influence of the anæsthetic a careful palpation revealed no evidence of intussusception or the presence of any swelling at all. The abdomen was opened below the umbilicus and the distended intestines were received into a warm sterilised towel. There was a little free fluid in the peritoneal cavity. On sweeping the hand under the liver a loop of small intestine was separated and brought out, which disclosed the site of the trouble. At the apex of the loop was a tuberculous ulcer which felt like a ring of cartilage let into the bowel. This had produced a local peritonitis and the loop, having become adherent somewhere under the liver, had produced an acute kink. The adhesions, which had been broken down by the hand in bringing the coil down from its original position, were very evident. There were a few large glands in the mesentery, one being of the size of a small walnut. The intestines were sponged over and returned and the abdominal walls were united in two layers with catgut and silkworm gut. The child made an uneventful recovery. The wound healed by first intention and the bowels, at first relieved by an enema, soon began to act without assistance. Careful feeding, with as much fresh air as possible, is being carried out, and as the next few months will be spent at the seaside there should be a reasonable chance of complete recovery.

Leicester.

\section{CESSATION OF RESPIRATION DURING AN ESTHESIA; RECOVERY AFTER ONE AND A QUARTER HOURS.}

By DAVID LAMB, M.B., C.M. Glasg., ANASTHETIST TO THE VICTORIA INFIRMARY, GLASGOW.

ON July 3rd, 1902, a well-built man, aged 26 years, was operated upon by Mr. A. E. Maylard on account of acute inflammatory mischief in the left mastoid region. On this occasion chloroform was the anæsthetic employed and from an anæsthetic point of view the operation was completed without incident. On August 15th the patient was again brought to the aræsthetic room, on this occasion under the 